\title{
rommhalina
}

(8)

Partes de um todo

Autor(es): $\quad$ Macedo, Helder

Publicado por: Imprensa da Universidade de Coimbra

URL persistente:

URI:http://hdl.handle.net/10316.2/42369

DOI:

DOl:https://doi.org./10.14195/978-989-26-1308-6_53

Accessed : $\quad$ 26-Apr-2023 11:55:13

A navegação consulta e descarregamento dos títulos inseridos nas Bibliotecas Digitais UC Digitalis, UC Pombalina e UC Impactum, pressupõem a aceitação plena e sem reservas dos Termos e Condições de Uso destas Bibliotecas Digitais, disponíveis em https://digitalis.uc.pt/pt-pt/termos.

Conforme exposto nos referidos Termos e Condições de Uso, o descarregamento de títulos de acesso restrito requer uma licença válida de autorização devendo o utilizador aceder ao(s) documento(s) a partir de um endereço de IP da instituição detentora da supramencionada licença.

Ao utilizador é apenas permitido o descarregamento para uso pessoal, pelo que o emprego do(s) título(s) descarregado(s) para outro fim, designadamente comercial, carece de autorização do respetivo autor ou editor da obra.

Na medida em que todas as obras da UC Digitalis se encontram protegidas pelo Código do Direito de Autor e Direitos Conexos e demais legislação aplicável, toda a cópia, parcial ou total, deste documento, nos casos em que é legalmente admitida, deverá conter ou fazer-se acompanhar por este aviso. 



\section{PARTES DE UM TODO}

Helder Macedo

Tendo-me sido dada a opção de colaborar nesta homenagem a Maria Irene Ramalho com um "texto académico" ou com um "testemunho", a amizade sobrepôs-se à admiração. No entanto, este testemunho de amizade inclui também o reconhecimento da scholar com quem tive o privilégio de partilhar alguns dos melhores momentos da minha vida académica. Refiro-me sobretudo, embora não apenas, aos vários anos em que participei nas avaliações, por ela lideradas, de centros e de projetos de investigação nas universidades portuguesas, beneficiando da sua extraordinária capacidade de reconciliar um rigoroso profissionalismo com uma profunda generosidade de sentimentos.

Nos seus estudos académicos, Maria Irene Ramalho demonstra a verdade fundamental que só se pode conhecer o que se ama. Que amor é conhecimento. Como diria um dos muitos poetas que partilhamos, W. B. Yeats, não se pode separar a dança de quem dança. O nosso também partilhado Fernando Pessoa terá dito, num dos seus aparentemente fragmentados disfarces, que o universo é partes sem todo. Mas isso só pode ser dito, como Maria Irene Ramalho bem sabe, por quem sabe que um todo é feito de partes só aparentemente fragmentadas.

Outro poeta que partilhamos é, obviamente, Luís de Camões. Que, tanto quanto Pessoa e Yeats, foi um poeta que procurou transformar 
a fragmentação do mundo aparente numa totalidade essencial. Para Camões, no entanto, a totalidade desejada era, ou deveria ter podido ser, um propósito humano realizável em vida e não uma transposição metafísica para o divino. E nisso talvez seja mais do nosso tempo do que esses dois poetas cronologicamente mais modernos ou, como outro exemplo pertinente, T. S. Eliot.

E aqui, querida Maria Irene, vou meter a minha foice camoniana na tua seara anglo-americana. Integrando o "texto académico" que não escrevi no "testemunho" que preferi escrever como parte das nossas nunca terminadas conversas de perene amizade.

Lembras-te certamente da fala de Lionardo no Canto IX (estrofes 75-82) d'Os Lusíadas. Esse "bem desposto" Lionardo - "manhoso, cavaleiro e namorado / a quem Amor não dera um só desgosto, / mas sempre fora dele mal tratado" - é, segundo entendo, caracterizado por Camões como um falso amador, porque tinha substituído a veracidade dos sentimentos por uma expressão poética literariamente bela mas existencialmente falsificadora. Por isso "Amor nunca lhe dera um só desgosto" e, sem a experiência de verdadeiramente amar, ele havia maltratado o Amor. Mas, por isso também, nunca tinha experimentado o gosto de amar. É essa experiência que, em vez de uma neoplatónica idealização incorporal, the vai ser oferecida na iniciática Ilha do Amor pela fisicalidade da "Ninfa", a quem ele confessa (citando o seu inevitável Petrarca. . .) que, até então, Tra la spica e la man qual muro he messo! ("Entre a espiga e a mão mete-se um muro"). A Ninfa - ainda assim seduzida pela beleza da poesia petrarquista. . . - finalmente cede, "volvendo o rosto, já sereno e santo, / toda banhada em riso e alegria", quando percebe que ele tinha aprendido a lição. E Lionardo, pela primeira vez, "todo se desfaz em puro amor". Mas tudo isso, é claro, é dito pelo Camões que sabia - e ensina - que carne e espírito são indissociáveis partes do mesmo todo que é o amor, enquanto que o soneto de Petrarca desenvolve o conceito de que o desejo é uma 
espécie de cegueira que destrói o coração (Se col cieco desir che'l cor distrugge).

Agora pergunto-te, Maria Irene, se concordas que esse verso de Petrarca citado por Camões é também ecoado por T. S. Eliot no poema The Hollow Men. Ou seja, se a "Sombra" de Eliot corresponde ao "muro" de Petrarca.

Eliot escreve, em The Hollow Men, que between the idea / and the reality/falls the Shadow. E não é só "entre a ideia e a realidade" que a "sombra" cai, mas também, em reiterações sucessivas do conceito, entre "o movimento e o ato", "a conceção e a criação", "a emoção e a resposta", "o desejo e o espasmo", "a potência e a existência", até culminar com a sombra a cair entre a divina "essência" e a sua "descida" ao mundo da matéria. Eliot, a seu modo, glosando Petrarca para dizer que sim, que entre a espiga e a mão há um muro intransponível. Enquanto que Camões - menos petrarquista do que Eliot - cita Petrarca para mostrar que não, que não é ou não deveria ser necessariamente assim.

Entre as muitas possíveis fontes literárias e filosóficas do poema de Eliot que têm sido detetadas pela crítica (Aristóteles, S. Tomás de Aquino, o pré-pessoano William James no The Meaning of Truth, e várias outras) não há, que eu saiba, qualquer referência ao "muro" do soneto de Petrarca. Mas isso pode ser ignorância minha e tu saberás melhor do que eu. Creio, em todo o caso, que a "sombra" que "cai" no poema de Eliot e o "muro" que se intrepõe à "mão" no soneto de Petrarca têm um significado equivalente. Além do mais, T. S. Eliot conhecia bem Petrarca. Bom, sim, mas, para seu prejuízo, não conhecia Camões. Ou, se conhecia, não partilhava a visão do mundo existencialmente redentora que, mesmo nos seus momentos de mais extremo desespero, o impediram de tornar-se num "homem esvaziado" para quem o mundo pudesse acabar "Not with a bang but a whimper".

Que te parece? Será que isto faz algum sentido? Como vês, querida Maria Irene, temos ainda muito para conversar. 